The issue of integration of the Armed Forces of Ukraine into the North Atlantic Treaty Organization has long been on the agenda. The experience of the countries that have recently joined the North Atlantic Treaty Organization shows that accession requires not only political and economic conditions, but also purely military ones. One of these conditions is military standardization, an activity that is to lay down provisions for common and repeated use of existing or potential missions and aimed at achieving an optimal degree of orderliness in the defense field.

The article deals with the basic terms and concepts of moral and psychological influence that defined in 1991-2018 the essence, main components and directions of activity of bodies and officials of structures of moral and psychological influence in the process of their formation, development and transformation in the Armed Forces of Ukraine.

The focus is on defining terms and concepts (definitions), explaining them, or interpreting meanings (meaning). The meaning of these terms and concepts from English-language sources and NATO standards is also given.

Keywords: personality, structure, moral and psychological influence, morality, social, psychology, humanitarian, provision, service, work, support, directions, components. 
УДК 355.098.(477)

DOI: 10.33099/2707-1383-2019-33-3-133-156

Чірікалов О.С., кандидат історичних наук, доцент кафедри Військово-Морських Сил командно-штабного інституту застосування військ (сил) Національного університету Оборони Украӥни імені Івана Черняховського (м. Київ)

\section{ЕВАКУАЦЙНІ ЗАХОДИ НІМЕЦЬКИХ ВІЙСЬК (СИЛ) ТА ЇХ СОЮЗНИКІВ НА СЕРЕДЗЕМНОМУ МОРІ У 1943 РОЦІ}

У статті проаналізовано досвід підготовки і проведення евакуащії німецььких військ (сил) та їх союзників на Середземному морі у 1943 роиі. Реконструйовано перебіг подій під час підготовки і ведення зазначених евакуаиійних заходів, висвітлено їх характерні риси та особливості, узагальнено досвід підготовки та ведення евакуачї німецьких військ (сил) та їх союзників на Середземному морі у 1943 році.

Ключові слова: дії з евакуачї військ (сил), евакуачія військ (сил) морем, контревакуаційні заходи, операчія з евакуації військ (сил), операція “Відплата” (operation “Retribution”), північноафриканський театр воєнних дій, середземноморський театр воєнних дій, Сицилійська операція, союзники антигітлерівської коаліції, Туніська кампанія.

В умовах триваючої збройної агресії Російської Федерації проти України, актуальним залишається пошук раціональних форм і способів застосування військ (сил) та визначення по- рядку управління ними в умовах переваги противника на театрі воєнних дій (далі - ТВД). Ймовірність реалізації варіанта "гібридного" вторгнення на територію України зберігається, тому 
не виключається можливість ситуації, коли у стислі терміни, саме в умовах переваги противника на ТВД, виникне необхідність у здійсненні евакуаційних заходів у тому числі морем. 3 огляду на це виникає необхідність проведення ретроспективного аналізу та вивчення досвіду підготовки і проведення таких операції (дій), особливо в умовах дефіциту часу. Корисним та необхідним для врахування є досвід евакуаційних заходів, здійснених німецькими військами (силами) та їх союзниками на Середземному морі у 1943 році.

Проведений автором історіографічний аналіз наукових доробків провідних зарубіжних, радянських та сучасних українських дослідників за вказаною тематикою свідчить про ii достатню репрезентативність для комплексного опрацювання обраної теми. Водночас, незважаючи на значну кількість праць, переважна більшість iз них мають виразну фрагментарність: автор не виявив цілісних, грунтовних та об’єктивних воєнно-історичних досліджень з цієї теми.

Мета статті полягає у розкритті та узагальненні досвіду підготовки та ведення евакуації німецьких військ (сил) та їх союзників на Середземному морі у 1943 році для його використання при вдосконаленні теорії і практики діяльності Військово-морських сил Збройних Сил України, передусім в умовах агресії Російської Федерації проти України.

Проведений автором аналіз [20] свідчить, що до початку здійснення евакуаційних заходів на Середземному морі у 1943 р. військове керівництво нацистської Німеччини та фашистської Італії не приділяло належної уваги питанням підготовки та проведення евакуації військ (сил): у керівних документах, що регламентували застосування військ (сил), зокрема військово-морського флоту під час ведення бойових дій, питання щодо визначення форм, способів i тактичних прийомів його застосування під час евакуації військ (сил) морем не розглядалися; евакуація військ (сил) як завдання німецькому (італійському) флоту визначено не було. У підсумку, як показали подальші події, відсутність вимог (положень) керівних документів із питань підготовки та проведення евакуаційних заходів морем вимагало від італійсько-німецького військового керівництва ініціативи, 
наполегливості, рішучості та неординарності при прийнятті рішень. Отже, результати евакуації безпосередньо залежали, у першу чергу, від особистих професійних якостей керівників та підготовленості органів військового управління і військ (сил).

Наприкінці квітня 1943 р. обстановка на північноафриканському ТВД для італійсько-німецьких військ була напруженою. Чинячи опір англо-американським військам, 26 квітня частини групи армій “Африка” були вимушені відступити на нові позиції на 270 км від Бізерти через практично повну відсутність постачання.

На той час союзні війська мали повну перевагу на суші, морі та у повітрі. Так, на суходолі угруповання союзників на той час нараховувало до 300 тис. осіб, до 2 тис. гармат та близько 1,1 тис. танків, а дев'ять німецьких дивізій - основа італійсько-німецької оборони - усього 60 тис. осіб, близько 500 гармат і менше 120 танків [1, с. 295; 3, с. 194; 7, c. 225]. Військово-повітряні сили союзників у Північній Африці мали у своєму складі до 3 тис. літаків. Захоплення основних аеродромів на туніському узбережжі дало можливість авіації союзників наносити масовані авіаційні удари по морських комунікаціях противника та портах Туніс $\mathrm{i}$ Бізерта, а також посилити підтримку з повітря дій своїх військ. Втрата аеродромів призвела до необхідності перебазування німецько-італійської авіації на Сицилію і відповідно відсутності повноцінного прикриття військ “Осі” з повітря у районі бойових дій [3, с. 194; 7, с. 225; 26, с. 189]. 322 квітня ескадрильї союзних винищувачів створили суцільну повітряну блокаду аеродромів противника, повністю паралізувавши дії залишків італійсько-німецької авіації [1, с. 292; 10, с. $240 ; 13$, с. 133]. Маючи також перевагу на морі в силах у районі бойових дій та свободу маневру, флот союзників до кінця квітня 1943 р. практично встановив морську блокаду туніського узбережжя і майже повністю перервав морські комунікації північноафриканського угруповання італійсько-німецьких військ, що вкрай негативно вплинуло на їх спроможності щодо ведення подальших успішних бойових дій. Ситуація була настільки критичною, що, за спогадами учасників подій [3, с. 197], у квітні 1943 р. Люфтваффе не мало мож- 
ливості знайти 35 галонів бензину ний список військовослужбовців, на добу для запуску радіолокаційної які, на тї думку, підлягають евакуастанції, а після 4 травня гостро постало питання продовольчого забезпечення особового складу.

Отже, оцінивши обстановку як вкрай важку, командувач групою армій “Африка" генерал-полковник Г.Ю. фон Арнім (Hans-Jürgen von Arnim) звернувся до вищого військового керівництва Рейху та особисто до А. Гітлера $з$ вимогою поставити його військам чіткі оперативні завдання 3 урахуванням реальної обстановки на ТВД, наполягаючи на необхідності проведення негайної евакуації. Водночас, не чекаючи на рішення вищого командування, Г.-Ю. фон Арнім самостійно розпочав здійснювати низку заходів: наполягав припинити відкомандировувати в його розпорядження офіцерів, направив у Ставку запит на евакуацію 600 військовослужбовців різних спеціальностей та офіцерів його армії, які виявилися незатребуваними внаслідок скорочення лінії фронту та реорганізації армійських штабів. Однак Ставка відхилила вказані пропозиції, конкретних оперативних задач не визначила, а 6 травня направила Г.-Ю. фон Арніму поіменції $[3$, с. 199; 11].

Командувач італійсько-німецької танкової армії італійський генерал Дж. Mecce (Giovanni Messe) також неодноразово звертався до вищого військового керівництва своєї країни щодо подальших дій його армії в обстановці, що склалася на північноафриканському ТВД. Однак на необхідності евакуації своїх військ він не наполягав [26, с. 189, 191$].$

Необхідно зазначити, що питання евакуації італійсько-німецьких військ 3 Північної Африки розглядалися Ставкою кілька разів. Ще у жовтні 1942 р. після залишення Тобрука, оцінивши стратегічну обстановку на північноафриканському ТВД, командувач групи армій “Африка” генерал-фельдмаршал Е. Роммель (Johannes Erwin Eugen Rommel) запропонував фюреру розпочати вивезення "якомога більшої кількості кадрових військових уночі підводними човнами, маленькими кораблями та літаками до Свропи”, однак А. Гітлер був категорично проти реалізації такого сценарію [19, с. 95]. 9 березня 1943 р. Е. Роммель, вважаючи, що “подальше перебування групи 
армій на африканському континенті є самогубством", повторно звернувся до фюрера $з$ пропозицією скоротити лінію фронту та відступити за лінію укріплень навколо порту Тунісу, створюючи, таким чином, район для проведення в подальшому евакуації військ Африканського корпусу. Проте і цей план А. Гітлер залишив без уваги [1, с. $289 ; 19$, с. 109].

Після додаткової підготовки, перегрупування та зосередження угруповання англо-американських військ на вузькій ділянці фронту в районі Меджез-єль-Баба, 6-7 травня 1943 р. союзникам вдалося прорвати оборону противника, просунутися на захід, вийти на узбережжя та захопити останні бази постачання італійськонімецьких військ у Північній Африці - порти Туніс і Бізерту. Частини групи армій “Африка” відійшли на мис Бон, очікуючи на евакуацію. На оборонних позиціях залишилися лише сили прикриття [3, с. 200; 7, с. 225 , 229; 9, с. 407; 13, с. 133].

Англо-американське командування, впевнене в тому, що противник спробує евакуювати війська 3 мису Бон морем та повітрям, для блокування морського простору силами авіації та флоту та недопущення евакуації італійсько-німецьких військ з Тунісу морем організувало та провело в період з 8 до 13 травня 1943 р. операцію "Ретрібьюшн" (operation "Retribution"). Вона проводилася одночасно 3 операцією “Флакс" (operation "Flax") іншою складовою дій союзників, яка мала на меті зірвати повітряне сполучення між оточеними частинами італійсько-німецької танкової армії на африканському континенті та Італі$\epsilon ю[2$, c. $115 ; 7$, c. $229 ; 14$, c. 446; 28]. Перевага в силах і раціональне їх використання дало змогу союзникам успішно провести зазначені операції. Використовуючи особливості місцевості, італійсько-німецькі війська на мисі Бон створили укріплені позиції і були готові чинити опір противнику. Водночас командування групи армій “Африка” вживало інтенсивних заходів, намагаючись вивезти максимально можливу кількість своїх військ, але практично усі спроби евакуації були зірвані: безліч невеликих човнів та суден були перехоплені чи потоплені, союзний флот захопив у полон 897 військовослужбовців противника [3, с. $201 ; 11 ; 14$, с. $446 ; 28]$. 310 травня 1943 р. на мисі Бон роз- 
почалася капітуляція італійсько-німецьких військ: 12 травня капітулював командувач групи армій “Африка” генерал-полковник Г.-Ю. фон Арнім, а 13 травня - 3 дозволу Б. Муссоліні командувач італійсько-німецької танкової армії маршал Італії Дж. Месі $[1$, с. $298 ; 7$, с. $229 ; 9$, с. $408 ; 10$, c. 240 ; $11 ; 13$, c. 133].

За різними даними [1, с. $298 ; 7$, с. $229 ; 9$, с. $409 ; 11 ; 13$, с. $133 ; 14$, с. 447] союзники захопили у полон від 233 до 252,4 тис. осіб (з яких 125-160 тис. склали німецькі військовослужбовці). Евакуюватися до Італії вдалося лише близько 700 особам. Ще близько 9 тис. осіб (переважно поранених та хворих) протягом квітня вдалося вивезти до створення союзниками комбінованої блокади, але не за планом евакуації [2, с. $116 ; 12$, с. $412 ; 28]$. Таким чином, результатом проведених італійськонімецьким командуванням евакуаційних заходів стало вивезення близько 0,3\% особового складу без озброєння та військової техніки. Виходячи 3 цього, евакуацію угруповання італійськонімецьких військ із Північної Африки слід вважати невдалою.

Безумовно, що в умовах, що склалися наприкінці квітня — початку травня
1943 р. у Північній Африці для військ “Осі”, проведення евакуаційних заходів тільки силами італійсько-німецької танкової армії було вкрай важким завданням. Вище військово-політичне керівництво Німеччини та Італії, виходячи iз політичних міркувань та “питань престижу” [11], не розглядало можливість та необхідність проведення повномасштабної евакуації північноафриканського угруповання своїх військ, тому ініціатором іï реалізації виступило командування групи армій “Африка”. Проте можливостей та спроможностей самостійно успішно реалізувати евакуаційні заходи в тих умовах у них практично не було. Часу на підготовчі заходи до проведення евакуації не вистачало, тому детальний план евакуації не розроблявся, а сама реалізація проводилася у формі дій $з$ евакуації.

На думку деяких дослідників [11], успішна евакуація італійсько-німецького угруповання військ 3 Північної Африки все ж була можлива у разі своєчасного прийняття рішення на іï проведення (початок квітня 1943 р.), завчасного планування та реалізації за підтримки сил італійського флоту. Після капітуляції італійсько-німець- 
ких військ у Тунісі, враховуючи зміни в обстановці на ТВД, командування Південного Заходу і Заходу (головнокомандувач - фельдмаршал А. Кессельрінг (Albert Kesselring) прийняло рішення евакуювати німецький гарнізон острова Пантеллерія повітряним шляхом. Операція була розпочата завчасно та успішно проведена — майже весь гарнізон було вивезено літаками Ju-52 до захоплення острова союзниками 11 червня 1943 р. [4].

На початку серпня 1943 р. італійсько-німецькі війська знову зіткнулися 3 необхідністю проведення евакуації в короткі терміни та в умовах переваги противника на ТВД. Після тривалих боїв, відступаючи під натиском союзників, італійсько-німецькі війська відступили в північно-східну частину острова Сицилія. Англо-американські війська, швидко просуваючись уздовж північного та східного узбережжя острова, намагалися захопити Мессіну та блокувати шляхи відходу військ противника в Італію через Мессінську протоку. Станом на 24 липня уся західна частина Сицилії вже була захоплена союзниками і вони продовжували активні наступальні дії: за підтримки сил флоту частини 7-ї американської армії розпочали наступ на Мессіну, а частини 8-ї британської армії з боями просувалися у напрямку Мессінської протоки. Союзники активно висаджували десанти в тилу німецьких військ, які були вимушені відходити під загрозою оточення. Проте, уміло здійснюючи маневр силами, 25 липня німцям вдалося закріпитися та зупинити просування союзників на позиціях, що проходили від Катанії до північного узбережжя острова.

Оцінивши обстановку, фельдмаршал А. Кессельрінг і командир 14-го танкового корпусу (XIV Panzer Corps) генерал Х.В. Хубе (Hans-Valentin Hube) звернулися до вищого військового керівництва Німеччини з пропозицією евакуювати сицилійське угруповання військ в Італію, однак А. Гітлер наполягав на утриманні Сицилії “до останньої людини", тому ухвалення остаточного рішення $з$ цього питання було відкладене. А. Кессельрінг, не чекаючи на відповідь від керівництва, 2 серпня 1943 р. особисто схвалив детальний план евакуації - операцію “Лерганг” (“Lehrgang") [22, c. 6; 24; 25].

Варто зазначити, що ще 14 липня, на четвертий день після висадки союзників на Сицилію (операція “Хаскі”), 
після обговорення з А. Кессельрінгом необхідності та можливості евакуації військ з Сицилії генерал Х. В. Хубе запропонував командирові 15-ї панцергренадерської дивізії полковнику Е. Г. Бааде (Ernst-Günther Baade) завчасно розпочати підготовку району Мессінської протоки до переправи та забезпечення іiі оборони з моря, повітря і суші $[10$, с. $251 ; 22$, с. $6 ; 24 ; 29$, с. 353]. Водночас А. Кессельрінг наказав приступити до розроблення плану евакуації (майбутній план операції “Лерганг”). Упродовж наступних трьох тижнів зусиллями Х. В. Хубе, Е. Г.Бааде, фрегаттен-капітана Г. фон Лібенштайна (Gustav Freiherr von Liebenstein) та італійського морського командира в Сицилії контр-адмірала П. Бароні (Pietro Barone) була проведена робота щодо зосередження військових і цивільних плавзасобів у портах протоки (дев'ять самохідних поромів “Siebel”, сім поромів-барж, морський пором, 12 штурмових для десантника, 41 легку інженерно-штурмову і 50 гумових човнів), визначено місця завантаження (розвантаження) - 12 пунктів, організовано порядок поромної переправи, здійснено технічне удосконалення морських засобів перевезення, додат- ково в районі протоки створено батареї протикорабельної та протиповітряної оборони (до 150 од. артилерії калібром від 75 до 280 мм) і посилено винищувальне прикриття району [6;16; 17; 22 , с. $7-9 ; 23 ; 24 ; 27$, c. $142 ; 31$, c. 63$]$. Вказані заходи дали змогу забезпечити інтенсивне та безперебійне постачання німецько-італійських військ на острові (у період з 1 по 10 серпня морем було перекинуто близько 12 тис. осіб, 4,5 тис. одиниць техніки і 15 тис. тонн вантажів [17]) та у той же час створити сприятливі умови для успішного проведення у разі необхідності евакуації через протоку. Одночасно продовжувалася робота над розробленням плану евакуації.

У процесі підготовчого етапу евакуації був визначений попередній порядок відходу німецьких військ з острова. А. Кессельрінг вважав, що повну евакуацію сицилійського угруповання німецьких військ (танкова "Герман Геринг" (panzer division "Herman Göering”), 15-a і 29-а панцергренадерські (panzegrenadier division), 1-а парашутна (parachute division) дивізіi) можливо провести протягом п'яти діб. Враховуючи зазначене, була затверджена послідовність відходу частин 
до пунктів завантаження 3 урахуванням стримування наступу противника, недопущення прориву лінії фронту та одночасного проведення евакуації. Завдання 3 прикриття евакуації було покладене на частини дивізії "Герман Геринг" [22, с. 12; 23].

Після затвердження А. Кессельрінгом плану евакуації, 3 серпня 1943 р. італійські війська розпочали поступове відведення та вивезення своїх військ (сил) під керівництвом контрадмірала П. Бароні з чотирьох поромних переправ до Сицилії. Для прискорення перевезення було задіяно 932-тонний пором “Villa", здатний взяти на борт до 3 тис. осіб за рейс $[6 ; 17 ; 22$, с. $14 ; 29$, с. $353 ; 33]$. Евакуація проводилася в умовах відсутності активних дій противника, тому проходила організовано та без втрат.

5 серпня 1943 р. німецьке командування неофіційно, а з 06.00 11-го, офіційно отримавши дозвіл від вищого керівництва, розпочало повну евакуацію своїх військ із Сицилії [16; 21; 23; $24 ; 33 ; 34$, c. 29].

В ар'єргардних боях, використовуючи характер місцевості, здійснюючи маневр силами, німцям вдалося уникнути оточення та затримати подальше просування противника до Мессінської протоки, одночасно здійснюючи евакуацію своїх військ. У цілому, незважаючи на деякі затримки у часі, евакуація проводилася згідно 3 планом: 311 по 13 серпня було вивезено особовий склад та техніку 15-ї панцергренадерської дивізії, у ніч 315 на 16-те - 29-ї панцергренадерської дивізії. Одночасно здійснювалося послідовне вивезення частин 1-ї парашутної та танкової дивізії “Герман Геринг”, що 15 серпня розпочала поступовий відхід із позицій із подальшою посадкою на плавзасоби у порту Мессіни (на той час останній пункт евакуації). О 06.3517 серпня останні німецькі та італійські військовослужбовці переправилися через Мессінську протоку. Увечері того ж дня війська генерал-лейтенанта Дж. См. Паттона (George Smith Patton) зайняли місто [4; 12, с. 410;16;17; 21; 22, с. 12,$24 ; 27$, с. $143 ; 31$, с. 84]. Вміле ведення ар'єргардних боїв разом із нерішучими наступальними діями союзників дали можливість німецькому командуванню за дві ночі безперешкодно вивезти 34 танки (включаючи “Тигр”), 44 штурмових гармати та до 12,5 тис. осіб $[6 ; 24]$. 
Усього у результаті операції “Лерганг” (з 11 по 17 серпня 1943 р.) за різними оцінками $[1$, с. $308 ; 6 ; 8$, с. 377 ; $17 ; 21 ; 23 ; 24 ; 33]$ через Мессінську протоку вдалося перевезти: 39569 німецьких солдатів і офіцерів, до 62 тис. італійських військовослужбовців (3 них 3 тис. моряків), 4444 поранених, 47 танків, 135 гармат (94 німецьких i 41 італійську), 9832 (9 605 німецьких i 227 італійських) одиниць техніки, більше 2 тис. тонн боєприпасів і пального, понад 15-17 тис. тонн матеріальних запасів. До 13,5 тис. осіб було вивезено силами транспортної авіації Люфтваффе [12, с. 426; 22, с. 14; 25; 30 , c. 164,$167 ; 31$, c. $89 ; 33 ; 34$, c. 29$]$.

Таким чином, евакуація італійськонімецьких військ із Сицилії була проведена успішно — в умовах панування противника на морі, суші та у повітрі упродовж шести днів вдалося вивезти близько 98 \% особового складу угруповання. Важливу роль при цьому зіграла пасивність дій союзників зі зриву евакуаційних заходів. Помилки в організації взаємодії, нераціональний розподіл наявних сил та засобів при виконанні завдань зі зриву евакуації та низка інших причин [6; 12, с. 427; $15 ; 22$, с. $90 ; 29$, с. $354 ; 30$, с. 165$] \mathrm{y}$ сукупності не дали змоги союзному командуванню зірвати евакуацію противника. Крім цього, створена у районі Мессінської протоки комплексна оборона значно ускладнювала та сковувала дії союзників, зокрема авіації. Так, за спогадами фон Лібенштайна, за результатами атаки 550 англо-американських літаків було вбито одного німецького солдата [22, с.14].

На думку воєнних дослідників [8, с. 377], англо-американське командування на той час мало можливості не тільки для успішного блокування Мессінської протоки та зриву евакуації німецько-італійських сил, а й для здійснення висадки своїх військ на півдні Апеннінського півострова. Проте нерішучість і зайва методичність союзників не дали змоги провести таку операцію.

У зв’язку з капітуляцією Італії 8 вересня 1943 р., а також висадкою союзників на Апеннінському півострові 13 вересня А. Гітлер віддав наказ про евакуацію військ (сил) із островів Сардинія і Корсика. Спочатку німецьке командування розраховувало утримувати під контролем обидва острови, однак із початком активації плану “Ось” (нім. "Achse” — воєнно-страте- 
гічна операція збройних сил Третього Рейху по захопленню території Італії і нейтралізації Королівської армії Італії) війська з Сардинії належало негайно евакуювати на Корсику для посилення його оборони $[4 ; 8$, с. $382 ; 18]$.

За наказом фельдмаршала А. Кессельрінга і під керівництвом командувача німецькими збройними силами на островах Сардинія і Корсика генерал-лейтенанта танкових військ Фр. фон Зенгера (Fridolin Rudolf Theodor, Ritter und Edler von Senger) у протоку Боніфачо були перекинуті самохідні пороми "Siebel” та інші дрібні судна, раніше залучені до евакуації військ із Сицилії. 314 по 18 вересня 1943 р. на Корсику морем був вивезений весь

гарнізон острова $-25,8$ тис. осіб, 4650 автомашин, 4765 тонн різних вантажів, 62 танки, 144 протитанкові гармати, 59 польових гармат різних типів, 119 88-мм зеніток, 147 20-мм зеніток і 30 20-мм зенітних установок $[15 ; 18 ; 32$, с. $279-280]$. Евакуація проводилася в умовах відсутності протидії з боку противника, тому пройшла організовано і без втрат.

Одночасно розпочалася евакуація німецько-італійських військ із Корсики, що здійснювалася морським і повітря- ним шляхом. За деякими даними [18], на початку евакуації на острові знаходилося близько 80 тис. італійських і до 30 тис. німецьких військовослужбовців. Станом на 16 вересня за підрахунками штабу німецького флоту евакуації підлягало близько 26 тис. німецьких та до 10 тис. італійських військовослужбовців без врахування особового складу, який додатково евакуювався з Сардинії [13, с. 145; 18]. Також планувалося вивезти техніку і військове майно - до 5 тис. різних автомашин, близько 100 танків та штурмових гармат, до 600 гармат і понад 4800 тонн матеріальних запасів. Евакуацію особового складу планувалося здійснити повітряним шляхом, техніку і майно морем [32, с. 282].

На початку проведення евакуаційних заходів оперативна обстановка на Корсиці була такою: німецькі війська контролювали південні порти, східне узбережжя і Бастію, а італійські та французькі повстанці - західне узбережжя і центр острова. Оцінивши обстановку, для проведення евакуації повітряним шляхом німецьке командування вирішило задіяти аеродроми в Гізоначчі і Борго-Бастії (пізніше в Порете), а для морської евакуації - 
декілька портів, головним із яких була Бастія, найбільш доцільний порт для вивезення особового складу і техніки морським шляхом.

Евакуація повітряним шляхом проводилася силами 2-ої транспортної ескадри та 290-ої транспортної ескадрильї Люфтваффе (близько $80 \mathrm{Ju}-52 /$ 3т, декілька SM-82 і Ме-323) [4; 18]. Евакуаційні заходи на морі здійснювалися під керівництвом фон Лібенштайна, який, маючи досвід успішного проведення евакуації із Сицилії, зміг раціонально розподілити та використати наявні плавзасоби з урахуванням того, що в цей же час тривав процес перевезення військ із Сардинії на Корсику. У той же час нестача транспортних засобів гостро відчувалася аж до 18 вересня 1943 р. - завершення евакуації сардинського угруповання. Проаналізувавши спроможності сил евакуації, генерал-лейтенант Фр. фон Зенгер наказав евакуювати мінімум по 3 тис. осіб в день, а також вивезти морем максимальну кількість техніки $[5$, с. $213 ; 18]$.

314 по 16 вересня 1943 р. активними діями німцям вдалося розширити плацдарм у районі Бастії, що дало змогу створити сприятливі умови в порту для завантаження та вивезення озброєння і військової техніки морем. 316 вересня евакуація німецько-італійських військ із острова стала для них першочерговим завданням. У цей день морським транспортом вдалося вивезти до Італії 80 автомобілів, 13 танків та 360 тонн різних вантажів, а також до 3 тис. осіб літаками [4; 18; 32, с. 296].

Перші три доби евакуація проходила згідно з планом: особовий склад вивозили повітряним шляхом 3 двох аеродромів (Гізоначчі та Борго-Бастії), а техніку - морем з Бастії. 18 вересня евакуація німецько-італійських військ з Сардинії завершилася, що дало змогу задіяти вільні плавзасоби до морських перевезень з Корсики. До 19 вересня включно морем вдалося вивезти 519 осіб, 169 автомашин, 6 гармат, 17 танків та 722 тонни майна. Цієї ж доби фельдмаршал А. Кессельрінг відвідав острів та віддав особисті вказівки щодо порядку проведення подальшої евакуації [5, с. 214; 18].

Починаючи з 20-го вересня різко посилилась активність дій союзників на морі та у повітрі: англо-американська авіація розпочала здійснювати систематичні нальоти на гавань Бастії та аеродроми, намагаючись зірвати евакуацію. 
Так, 21 вересня на порт було здійснено два нальоти силами 33 важких бомбардувальників, в результаті яких було потоплено 2 пароплави, 2 невеликі судна та 2 самохідні пороми “Siebel”, а 29 вересня в результаті бомбардування тимчасово був виведений з ладу аеродром у Борго [5, с. 215]. Це призвело до тимчасового зниження інтенсивності евакуаційних заходів: 29 вересня морем вдалося вивезти лише 86 осіб, 55 автомашин, 19 гармат та 151 тонну майна [18]. Союзники широко стали застосовувати винищувальну авіацію, щоб зірвати евакуацію повітряним шляхом. Так, у результаті повітряних боїв 25 вересня над морем було збито 11 транспортних літаків Ju-52 [5, с. 215; 18]. У результаті евакуація повітрям стала здійснюватися тільки у нічний час, коли союзні винищувачі не проявляли активності.

У морі стали активно діяти підводні човни союзників. Так, 22 вересня на переході морем у результаті їхніх дій було потоплено пароплав "Chapman" 3 військами на борту. У зв'язку з цим німецьке командування основну ставку зробило на самохідні пороми "Siebel" та невеликі ліхтери з малою осадкою. Проте зазначені плавзасоби нерідко переверталися через осінні шторми [5, c. $215 ; 18]$.

Разом з тим пасивні дії союзників на острові в період з 19 по 24 вересня 1943 р. дали змогу німецько-італійським військам планово продовжувати евакуацію: в умовах відсутності активних дій противника 22 вересня був повністю евакуйований плацдарм у Боніфачо, 23 вересня німецькі війська залишили Порто-Веккьо, 24-го — аеропорт Гізоначчі. Перш ніж залишити вказані райони, німці встигли підірвати 60 мостів, знищити усі портові споруди у Боніфачо та Порто-Веккьо, вивести з ладу злітну смугу аеродрому [5, с. $215 ; 18]$.

У період з 25 вересня по 2 жовтня 1943 р. німці успішно утримували позиції, прикриваючи плацдарми в районі Бастії, з яких здійснювалося завантаження на плавзасоби. Тим часом союзники, перегрупувавши сили та поповнивши їх технікою та боєприпасами, були готові до проведення рішучого наступу на позиції противника. Проаналізувавши обстановку, 2 жовтня фон Лібенштайн прискорив процес евакуації, для чого відправив 3 Бастії одразу 36 максимально завантажених самохідних поромів "Siebel” та 
інших плавзасобів з військами, намагаючись одним рейсом вивести максимально можливу кількість особового складу та техніки. Однак вивезти все не вдалося [18; 32, с. 311].

У ніч на 3 жовтня, згідно з планом, був залишено аеропорт Борго, а о 19.00 того ж дня під прикриттям загороджувального вогню п'ять поромів вивезли зенітні батареї та основний особовий склад без сил прикриття. 317.15 Бастія знаходилася під безперервним артилерійським обстрілом противника, через що деякі судна доводилося завантажувати в скрутних умовах прямо з пляжу. Проте завантаження йшло безперервно. Останнє судно, на якому знаходилися сили прикриття, відійшло о 21.00. Усього за 3 жовтня 1943 р. з Бастії вдалося вивезти морем 2282 військовослужбовців, 222 військовополонених, 328 автомобілів, 51 гармату та 77 тонн майна. Залишена техніка, невитрачені боєприпаси, портове устаткування i ряд різних важливих об'єктів у місті були знищені, пошкоджені або виведені з ладу [18]. Згідно з дослідженням [18], усього на Корсиці було залишено (а також втрачено у боях) не менше 2,5 тис. різних автомобілів та понад 300 гармат; танки, штурмові гармати та матеріальні запаси вдалося евакуювати практично повністю.

За даними публікацій $[4 ; 18 ; 32$, с. 378], у результаті проведених евакуаційних заходів з Корсики вдалося вивезти до 35 тис. осіб (з них повітряним шляхом — 27 тис., включаючи італійський парашутний полк) - близько 98,5 \%, до 2,5 тис. різних автомашин, близько 100 танків і штурмових гармат, до 300 гармат та понад 5 тис. тонн матеріальних запасів.

Підсумовуючи вищевикладене, можна зробити такі висновки. У період з травня по жовтень 1943 р. на Середземному морі німецько-італійські війська (сили) провели низку евакуаційних заходів у формі міжвидової операції (Сицилія, Сардинія та Корсика) та дій $з$ евакуації (Туніс). Вказані операції із евакуації були успішними за результатами, а дії з евакуації невдалими. У результаті проведених евакуаційних заходів вдалося вивезти до 178 тис. осіб (з них повітряним шляхом до 40 тис.), при цьому, за винятком Тунісу, з інших районів вдалося вивезти значну кількість озброєння, військової техніки та матеріальних засобів.

Результати розглянутих евакуацій 
залежали не тільки від професійних та особистих якостей окремих керівників, підготовленості органів військового управління до виконання завдань в умовах динамічних змін в обстановці, а й від характеру та активності дій союзників, які мали на той час перевагу в силах на ТВД. У тих випадках, коли англо-американське командування не змогло ефективно використати свої спроможності щодо ведення контревакуаційних дій, евакуація військ (сил) противника була проведена успішно.

Підготовчий етап вказаних евакуацій мав характерні риси:

- відсутність діючих керівних документів (положень) із питань евакуації військ (сил) на початок зазначених евакуаційних заходів;

- при плануванні евакуації для збільшення обсягів перевезень передбачалося залучення цивільних плавзасобів.

Особливостями підготовки розглянутих евакуацій військ (сил) були:

- планування евакуації розпочиналося безпосередньо з отриманням рішення від вищого керівництва (Сардинія та Корсика) чи завчасно, не чекаючи на таке рішення (Туніс, Сицилія). При цьому втручання у процес підготовки евакуації північноафриканського угруповання вищого керівництва вермахту та особисто А. Гітлера призвело до ії фактичного зриву та унеможливило подальші дії щодо успішного проведення евакуаційних заходів;

- підготовка до евакуації італійськонімецьких військ 3 Тунісу здійснювалася за ініціативою командування зазначеного угруповання та із залученням власних сил в умовах, коли оперативна обстановка в районі вже не давала можливості здійснювати завантаження та перевезення основної маси військ морським і повітряним шляхом;

- проведення евакуації військ (сил) із Сардинії, Корсики та Сицилії планувалося провести у формі операції, а евакуацію північноафриканського угруповання - у формі дій з евакуації.

Характерні риси проведення розглянутих евакуацій полягали в тому, що вони:

- мали загальну мету - запобігання, мінімізація втрат особового складу, військової техніки і матеріальних засобів під час бойових дій, тобто були вимушені; 
- планувалися та проводилися із залученням сухопутних військ, авіації та флоту (крім італійського) за різними варіантами їх застосування;

- планувався та реалізувався тільки один спосіб проведення евакуації військ (сил) - послідовний відвід військ із плацдармів, ділянок узбережжя, портів, що оборонялися, з подальшим завантаженням на плавзасоби i перевезенням морським шляхом мінімально можливою кількістю рейсів.

Етап проведення вказаних евакуацій мав певні особливості, зокрема:

- діï із евакуації військ північноафриканського угруповання здійснювалися в умовах щільної комбінованої блокади союзників;

- для евакуації військ (сил) із Сардинії та Корсики широко застосовувалася транспортна авіація, що дало змогу збільшити обсяг перевезень;
- у період проведення розглянутих евакуацій сили союзників мали повну кількісну перевагу на ТВД, проте успішно реалізувати свої спроможності при здійсненні контревакуаційних заходів їм вдалося лише при зриві дії 3 евакуації німецько-італійських військ (сил) північноафриканського угруповання з Тунісу.

Можливі перспективні напрями продовження досліджень за зазначеною тематикою:

- еволюція військово-теоретичних поглядів на застосування сил флоту в ході підготовки та ведення евакуаційних заходів морем;

- застосування сил флоту в ході підготовки та ведення евакуаційних заходів морем у війнах та воєнних конфліктах XX століття. 


\section{Список використаних джерел і літератури}

1. Александер Б. 10 фатальных ошибок Гитлера / Пер. с англ. - М.: Издательство “Яуза”, Издательство “Эксмо”, 2003. — 448 с.

2. Брєдли О. Записки солдата / Пер. с англ. В. С. Столбова, Н. Н. Яковлева - М.: Издательство иностранной литературы, 1957. - 608 с.

3. Головушки В. И. Вторая мировая война. Битва за Африку: Взгляд из России / В. И. Головушкин. - М.: ООО “Издательство АСТ”; ЗЛО НПП “Ермак”, 2004. - 429, [3] с.

4. Дегтев Д. М. Воздушные извозчики вермахта [Транспортная авиация люфтваффе, 1939-1945]: Електрон. ресурс]. — Режим доступу: https:// military.wikireading.ru/13051.

5. Зенгер Ф. Ни страха, ни надежды. Хроника Второй мировой войны глазами немецкого генерала. 1940-1945 / Пер. с англ. Л. А. Игоревского. - М.: ЗАО “Центрполиграф”, 2003. - 479 с.

6. Исаев А. Бегство с Сицилии, или эвакуация по-немецки: [Електрон. pecyрc]. — Режим доступу: http://alternathistory.com/content/begstvo-s-siciliiili-evakuaciya-po-nemecki.

7. История Второй мировой войны в 12 томах Том 6. Коренной перелом в войне. / Под ред. И. В. Паратькина, ред. кол.: Г. Е. Хорошилов, В. В. Возненко, В. Е. Зубаков, Н. И. Макаров и др. - М.: Воениздат, 1976. - 520 с.

8. История Второй мировой войны в 12 томах Том 7. Завершение коренного перелома в войне. / Под ред. Б. Г. Соловьева, ред. кол.: Г. А. Колтунов, И. И. Гаглов, В. И. Клоков и др. - М.: Воениздат, 1976. — 552 с.

9. Карель П. Второй фронт. Книга IV. Африка 1941-1943. Нормандия 1944. / Пер. с англ. А. Колина, пер. с нем. В. Годфрида. - М.: Издательство “Эксмо", 2008. - 656 с.

10. Кессельринг А. Люфтваффе: триумф и поражение. Воспоминания фельдмаршала Третьего рейха. 1933-1947 / Пер. с англ. Л. А. Игоревского. — М.: ЗАО “Центрполиграф”, 2003. - 494 с.

11. Кох Л. Лис пустыни. Генерал-фельдмаршал Эрвин Роммель: [Елек- 
трон. ресурс]. — Режим доступу: http://militera.lib.ru/bio/koch/index.html.

12. Лиддел Гарт Б. Вторая мировая война. Очерк. / Пер. с англ. В. В. Борисова, П. Н. Видуєцкого и Е. Л. Цылева под. ред. и с предисл. О. А. Ржешевского. - М: Воениздат, 1976. - 679 с.

13. Мировая война. 1939-1945. — М: ООО “Издательство АСТ”; СПб.: ООО “Издательство Полигон”, 2000. - 736 с.

14. Морисон С. Э. Американский ВМФ во Второй мировой войне: Операции в водах Северной Африки, октябрь 1942-июль 1943 / Пер. с англ. Д. Б. Котельникова. - М.: “Издательство АСТ”; СПб.: Terra Fantastica, 2003. - 544 с.: ил., 16 л. ил.

15. Морисон С. Э. Флот двух океанов: [Електрон. ресурс]. - Режим доступу: https://www.litmir.me/br/?b=285718.

16. Нимиц Честер Война на море (1939-1945): [Електрон. ресурс]. — Режим доступу: https://royallib.com/read/nimits_chester/voyna_na_more_1939_1945. html\#0.

17. Операция Lehrgang Räumung von Sizilien vom 15. bis 17. August 1943: [Електрон. peсурс]. — Режим доступу: https://codenames.info/operation/lehrgang/.

18. Пономаренко Р. Корсиканский фронт Второй мировой // Арсенал-Коллекция 2015 № 12 (42): [Електрон. ресурс]. — Режим доступу: https://www. litmir.me/br/?b=581206.

19. Реми М. Ф. Миф Роммеля. Легенда Африканского корпуса / Пер. с нем. Я. Зверева, С. Бойко. - М.: АСТ: АСТ МОСКВА, 2008. - 270, [2] с.: ил.

20. Чірікалов О. С. Погляди військових теоретиків Німеччини щодо питань взаємодії армії та флоту в передвоєнний період // Збірник наукових праць Національного університету оборони України "Воєнно-історичний вісник". - К.: НУОУ, 2012. - Вип. 3(5) - С.106-113.

21. Этот день в истории: [Електрон. ресурс]. — Режим доступу: https:// Www.history.com/this-day-in-history/germans-begin-to-evacuate-sicily.

22. Barton V. Barnhart. The great escape: an analysis of allied actions leading to the axis evacuation of Sicily in World War II. - Fort Leavenworth, Kansas, 2003. $-112 \mathrm{p}$. 
23. German evacuation order — Sicily: [Електрон. ресурс]. — Режим доступу: http://www.lonesentry.com/articles/ttt/german-order-sicily-wwii.html.

24. Germanwarmachine: [Електрон. ресурс]. — Режим доступу: https:// germanwarmachine.com/despatches/wehrmacht-in-action/the-axis-evacuationof-sicily-1943.

25. Jürgen Rohwer zusammen mit Gerhard Hümmelchen Chronik des Seekrieges 1939-1945. Herausgegeben von der Bibliothek für Zeitgeschichte: [Електрон. ресурс]. - Режим доступу: http://www.wlb-stuttgart.de/seekrieg/ chronik.htm.

26. Messe G. Come finì la guerra in Africa. La "Prima armata" italiana in Tunisia. - Milano, Rizzoli, 1946. - 238 p.

27. Morison Samuel Eliot Sicily - Salerno - Anzio, January 1943 - June 1944. — United States, New Ed edition, 2001. — 440 p.

28. Operation Retribution (1943): [Електрон. ресурс]. — Режим доступу: https://www.revolvy.com/page/Operation-Retribution-\%281943\%29.

29. Friedrich von Stauffenberg The Battle of Sicily: How the Allies Lost Their Chance for Total Victory — United States, Stackpole Books, 2007. — 368 p.

30. Timothy D. Saxon. The German Side of the Hill: Nazi Conquest and Exploitation of Italy, 1943-45. - University of Virginia, 1999. - 378 p.

31. Steven J. Zaloga. Sicily 1943: The debut of Allied joint operations (Campaign) - Osprey Publishing, 2013. — 96 p.

32. Yerger M. German Cross in Gold, Vol.4. — Bender Publishing, 2009. $368 \mathrm{p}$.

33. Williamson Mitch. German Retreat from Sicily: [Електрон. ресурс]. Режим доступу: http://italy1943-45.blogspot.com/2015/08/german-retreatfrom-sicily.html.

34. Windsor Lee. "The Eyes of All Fixed on Sicily" Canada's Unexpected Victory. - Canada, 2012. - 34 p. 


\section{References}

1. Aleksander B. 10 fatal'nykh oshibok Gitlera / Per. s angl. - M.: Izdatel'stvo "Yauza", Izdatel'stvo "Eksmo", 2003. - 448 s.

2. Brêdli O. Zapiski soldata / Per. s angl. V.S. Stolbova, N.N. Yakovleva. M.: Izdatel'stvo inostrannoy literatury, 1957. - $608 \mathrm{~s}$.

3. Golovushki V.I. Vtoraya mirovaya voyna. Bitva za Afriku: Vzglyad iz Rossii / V.I. Golovushkin. - M.: OOO "Izdatel'stvo AST"; ZLO NPP "Yermak", 2004. — 429 s.

4. Degtev D.M. Vozdushnyye izvozchiki vermakhta [Transportnaya aviatsiya lyuftvaffe, 1939-1945]: Yelektron. resurs]. — Rezhim dostupu: https://military. wikireading.ru/13051.

5. Zenger F. Ni strakha, ni nadezhdy. Khronika Vtoroy mirovoy voyny glazami nemetskogo generala. 1940-1945 / Per. s angl. L.A. Igorevskogo. — M.: ZAO “Tsentrpoligraf”, 2003. - 479 s.

6. Isayev A. Begstvo s Sitsilii, ili evakuatsiya po-nemetski: [Yelektron. resurs]. - Rezhim dostupu: http://alternathistory.com/content/begstvo-ssicilii-ili-evakuaciya-po-nemecki.

7. Istoriya Vtoroy mirovoy voyny v 12 tomakh Tom 6 . Korennoy perelom v voyne. / Pod red. I.V. Parat'kina, red. kol.: G.Y. Khoroshilov, V.V. Voznenko, V.Y. Zubakov, N.I. Makarov i dr. — M.: Voyenizdat, 1976. - 520 s.

8. Istoriya Vtoroy mirovoy voyny v 12 tomakh Tom 7. Zaversheniye korennogo pereloma v voyne. / Pod red. B.G. Solov'yeva, red. kol.: G.A. Koltunov, I.I. Gaglov, V.I. Klokov i dr. — M.: Voyenizdat, 1976. - 552 s.

9. Karel' P. Vtoroy front. Kniga IV. Afrika 1941—1943. Normandiya 1944. / Per. s angl. A. Kolina, per. s nem. V. Godfrida. - M.: Izdatel'stvo "Eksmo", 2008. - $656 \mathrm{~s}$.

10. Kessel'ring A. Lyuftvaffe: triumf i porazheniye. Vospominaniya fel'dmarshala Tret'yego reykha. 1933-1947 / Per. s angl. L.A. Igorevskogo. M.: ZAO “Tsentrpoligraf”, 2003. - 494 s.

11. Kokh L. Lis pustyni. General-fel'dmarshal Ervin Rommel': [Yelektron. resurs]. — Rezhim dostupu: http://militera.lib.ru/bio/koch/index.html. 
12. Liddel Gart B. Vtoraya mirovaya voyna. Ocherk. / Per. s angl. V.V. Borisova, P.N. Viduêtskogo i Ye.L. Tsyleva pod. red. i s predisl. O.A. Rzheshevskogo. M: Voyenizdat, 1976. - 679 s.

13. Mirovaya voyna. 1939-1945. - M: OOO "Izdatel'stvo ACT"; SPb.: OOO “Izdatel'stvo Poligon”, 2000. — 736 s.

14. Morison S.E. Amerikanskiy VMF vo Vtoroy mirovoy voyne: Operatsii v vodakh Severnoy Afriki, oktyabr' 1942-iyul' 1943 / Per. s angl. D.B. Kotel'nikova. - M.: “Izdatel'stvo AST”; SPb.: Terra Fantastica, 2003. - 544 s.

15. Morison S.E. Flot dvukh okeanov: [Yelektron. resurs]. — Rezhim dostupu: https://www.litmir.me/br/?b=285718.

16. Nimits Ch. Voyna na more (1939-1945): [Yelektron. resurs]. — Rezhim dostupu: https://royallib.com/read/nimits_chester/voyna_na_more_1939_1945.html\#0.

17. Operatsiya Lehrgang Räumung von Sizilien vom 15. bis 17. August 1943: [Elektron. resurs]. — Rezhim dostupa: https://codenames.info/operation/ lehrgang/.

18. Ponomarenko R. Korsikanskiy front Vtoroy mirovoy // Arsenal-Kollektsiya 2015 № 12 (42): [Elektron. resurs]. — Rezhim dostupa: https://www.litmir.me/ $\mathrm{br} / \mathrm{?b}=581206$.

19. Remi M.F. Mif Rommelya. Legenda Afrikanskogo korpusa / Per. s nem. YA. Zvereva, S. Boyko. - M .: AST: AST MOSKVA, 2008. - $270 \mathrm{~s}$.

20. Chirikalov A.S. Vzglyady voyennykh teoretikov Germanii po voprosam vzaimodeystviya armii i flota v predvoyennyy period // Sbornik nauchnykh trudov Natsional'nogo universiteta oborony Ukrainy "Voyenno-istoricheskiy vestnik". - M .: NUOU, 2012. - Vyp. 3 (5) - S. 106-113.

21. Etot den' v istorii: [Elektron. resurs]. - Rezhim dostupa: https://www. history.com/this-day-in-history/germans-begin-to-evacuate-sicily.

22. Barton V. Barnhart. The great escape: an analysis of allied actions leading to the axis evacuation of Sicily in World War II. - Fort Leavenworth, Kansas, 2003. - $112 \mathrm{p}$.

23. German evacuation order — Sicily: [Elektron. resurs]. — Rezhim dostupa: http://www.lonesentry.com/articles/ttt/german-order-sicily-wwii.html. 
24. Germanwarmachine: [Elektron. resurs]. - Rezhim dostupa: https:// germanwarmachine.com/despatches/wehrmacht-in-action/the-axis-evacuationof-sicily-1943.

25. Jürgen Rohwer zusammen mit Gerhard Hümmelchen Chronik des Seekrieges 1939-1945. Herausgegeben von der Bibliothek für Zeitgeschichte: [Elektron. resurs]. - Rezhim dostupa: http://www.wlb-stuttgart.de/seekrieg/ chronik.htm.

26. Messe G. Come finì la guerra in Africa. La "Prima armata" italiana in Tunisia. - Milano, Rizzoli, 1946 - 238 p.

27. Morison Samuel Eliot. Sicily - Salerno - Anzio, January 1943 - June 1944. - United States, New Ed edition, 2001. - 440 p.

28. Operation Retribution (1943): [Elektron. resurs]. — Rezhim dostupa: https://www.revolvy.com/page/Operation-Retribution-\%281943\%29.

29. Friedrich von Stauffenberg The Battle of Sicily: How the Allies Lost Their Chance for Total Victory - United States, Stackpole Books, 2007. - 368 p.

30. Timothy D. Saxon. The German Side of the Hill: Nazi Conquest and Exploitation of Italy, 1943-45. — University of Virginia, 1999. — 378 p.

31. Steven J. Zaloga. Sicily 1943: The debut of Allied joint operations (Campaign) - Osprey Publishing, 2013. — 96 p.

32. Yerger M. German Cross in Gold, Vol. 4. — Bender Publishing, 2009. $368 \mathrm{p}$.

33. Williamson Mitch. German Retreat from Sicily: [Elektron. resurs]. Rezhim dostupa: http://italy1943-45.blogspot.com/2015/08/german-retreatfrom-sicily.html.

34. Windsor Lee "The Eyes of All Fixed on Sicily" Canada's Unexpected Victory. - Canada, 2012. - 34 p. 
Chirikalov O.S., Candidate of Historical

Sciences, Associate Professor of the

Department of Naval Forces of the command

and staff institute for the use of forces (forces)

of Ivan Chernyakhovsky National Defence

University of Ukraine (Kyiv)

\section{THE EVACUATION MEASURES OF THE GERMAN \\ TROOPS AND THEIR ALLIES IN THE \\ MEDITERRANEAN IN 1943}

The author analyzes the experience of preparing and conducting the evacuation of German troops (forces) and their allies in the Mediterranean in 1943.

The historical analysis of the scientific achievements of leading foreign, Soviet, and contemporary Ukrainian researchers on the subject indicated by the author testifies to its sufficient representativeness for complex elaboration of the chosen topic. At the same time, in spite of the considerable number of works, in their majority they have a distinct fragmentation: the author does not find comprehensive, thorough and objective military-historical researches on this topic. Therefore, there is a need for scientific generalization of the indicated experience of using troops (forces) in the preparation and conduct of evacuation measures at sea and the development of naval art, as a theoretical basis for solving scientific and practical problems.

The purpose of the article is to expose and summarize the experience of preparing and conducting the evacuation of German troops (forces) and their allies in the Mediterranean in 1943 for its use in improving the theory and practice of the Navy of the Armed Forces of Ukraine, especially in the face of aggression by the Russian Federation Of Ukraine.

The article analyzes and explores the main causes and factors that directly affected the preparation and conduct of the evacuation of German troops (forces) 
and their allies in the Mediterranean Sea in 1943 and, as a result, influenced its final results.

The course of events during the preparation and conduct of these evacuation measures was reconstructed, their characteristics and features were outlined, the experience of preparing and conducting the evacuation of German troops (forces) and their allies in the Mediterranean in 1943 was summarized.

Keywords: evacuation of troops (forces), evacuation of troops (forces) by sea, counter-evacuation operations, operation of evacuation of troops (forces), Operation "Retribution", North African theater of military action, Mediterranean theater of military operations, Mediterranean military theater, the Tunisian campaign. 